\title{
Effect of Socio Economic Status on Academic Performance of Secondary School Students
}

\author{
Mushtaq Ahmad Bhat ${ }^{1}{ }^{*}$, Dr. Jyotsna Joshi ${ }^{2}$, Irfan Ahmad Wani ${ }^{3}$
}

\section{ABSTRACT}

Aim: - The most important task of the educational system is to prepare students to acquire knowledge and career and cognitive skills to enter the community. Therefore, identifying the factors leading to the students' academic achievement is very important. The present study aimed to investigate the relationship between socio economic status and academic achievement of secondary school students belonging to different educational zones of Ganderbal district of Jammu and Kashmir State. Methods: - This descriptive analytical study was done on 120 students of secondary Schools in 2012-13 through random sampling. Socio economic status scale constructed and standardized by Rajbir Singh et al., and Previous Academic Progress Record from schools were used to collect data. Data were analyzed by using Mean, S.D, M.D and students t-test. Results: - Result proves it beyond any shadow of doubt that there is a significant difference in the academic achievement of high socioeconomic status of students in comparison to low socioeconomic status of students. Significant differences were found between the students with (high and low) and (high and middle) socioeconomic status. On the other hand insignificant difference was found between the students with middle and low socioeconomic status in respect to academic achievement.

Keywords: Parental Socio-economic Status, Academic Performance, Secondary school students.

Socioeconomic status is the blend of economic and sociological measures of an individual work experience and the economic and social position of an individual or family in connection to others on the premise of income, educational level and occupational status. For the investigation of a family socioeconomic status, the household income, education of earner and occupation are checked and in addition consolidated wage contrasted and a person, when their own attributes are assessed. Socioeconomic status is by and large partitioned into three categories i.e., high

\footnotetext{
${ }^{1}$ Research Scholar Dept. of Psychology B.U. Bhopal, (M.P), India

${ }^{2}$ Assistant Professor Dept. of Psychology S.N.G.G.P.G. College Bhopal (M.P), India

${ }^{3}$ Research Scholar Dept. of Psychology B.U. Bhopal, (M.P), India

*Responding Author

(C) 2016 I M Bhat, J Joshi, I Wani; licensee IJIP. This is an Open Access Research distributed under the terms of the Creative Commons Attribution License (http://creativecommons.org/licenses/by/2.0), which permits unrestricted use, distribution, and reproduction in any Medium, provided the original work is properly cited.
} 


\section{Effect of Socio Economic Status on Academic Performance of Secondary School Students}

socioeconomic status, middle socioeconomic status and low socioeconomic to clarify the three fields a family or an individual may fall into. At the point when putting a family or individual into one of these classifications, any or the majority of the three variables i.e., income, education, and occupation can be investigated and evaluated.

The obligation of training a child always lies in the hand of the parents. This is harmonious with the regular attestation sociologist that education can be an instrument of social change which is being taught from home is important in this talk about. It is not strange to envision that parental socio economic foundation can effect sly affect the academic achievement of children in school. At all influence the advancement environment of youngsters would perhaps influence their training or attitude to it. Parental status is one of such variables.

Socio economic status of parents do not only affect the academic performance, but also makes it possible for children from low background to compete well their counterparts from high socio economic background under the same academic environment (Rothestein, 2004). Education is a tool of development. It widens minds, recognizes good and bad, makes us to segregate well from terrible and uses out environment to the best of our capacity for the improvement of a person and in addition the group (Sabzwari, 2004).

Rich source of literature is available which highlights the impact of socio economical status on academic performance like Suleman et al., (2012) who found that children with strong socioeconomic status show better academic performance in comparison to those with poor socioeconomic status, they showed poor and unsatisfactory academic performance. Saifi (2011) investigated the effect of socioeconomic status on student's performance. Results revealed that parental education and occupation and facilities at home affect the student's achievement. Eamon (2005) revealed that students whose parental socioeconomic status is low do not show effective performance in school. Findings also showed that the academic achievement of students is negatively correlated with the low parental socioeconomic status level as it prevents the individual in gaining access to sources and resources of learning.

\section{Problem: -}

- To investigate the effects of parental socioeconomic status on the academic achievement of secondary school students.

\section{OBJECTIVES}

1. To see the relationship between the socioeconomic status of the parents and the academic performance of their children's.

2. To find out the effect of socioeconomic status on the academic performance of secondary school students.

3. To see the difference on academic achievement of students between high and low socioeconomic status. 


\section{Effect of Socio Economic Status on Academic Performance of Secondary School Students}

4. To see the difference on academic achievement of students between middle and low socioeconomic status.

5. To see the difference on academic achievement of students between high and middle socioeconomic status.

6. To suggest workable recommendations for the enhancement of the students academic performance.

\section{Hypotheses}

H1- There would be significant difference on academic achievement of students between high and low socioeconomic status.

H2-There would be significant difference on academic achievement of students between middle and low socioeconomic status.

H3- There would be significant difference on academic achievement of students between high and middle socioeconomic status.

\section{Variables:}

In the present study the investigator takes three independent variables viz sex (male \& female), area (rural \& urban) and socio economic status. Academic achievement is dependent variable.

\section{Sample:}

The sample for the present study consisted of 120 secondary school students selected through random sampling technique from 12 higher secondary schools on different educational zones of Ganderbal District in J\&K State.

\section{Measuring Tools:}

Socio-Economic Status Scale Standardized by Rajbir Singh et al., and Previous Years Academic Progress Report were used to collect data.

\section{Statistical Treatment:}

The data collected was analyzed by Mean and S.D. and t-test was used for hypotheses testing.

\section{RESULTS}

The main purpose of the present study was investigating the effects of parental socioeconomic status on the academic achievement of secondary school students. For this purpose investigator formulated 3 different hypotheses. Results are shown in below given tables besides it graphical representation of the mean scores is also mentioned. 
Effect of Socio Economic Status on Academic Performance of Secondary School Students

Table-1, Showing Mean, Standard Deviation, Mean Difference, and $t$ value of High and Low Socioeconomic Status

\begin{tabular}{|c|c|c|c|c|c|c|}
\hline Students & N & Mean & S.D & M.D & df & t- value \\
\cline { 1 - 4 } High SES & 40 & 67.52 & 16.86 & & & \\
\cline { 1 - 4 } Low SES & 40 & 58.16 & 16.99 & 9.36 & 78 & $2.47^{*}$ \\
\hline
\end{tabular}

*significant at 0.05 level

Graph-1 Graphical representation of mean scores of High and Low Socioeconomic Status

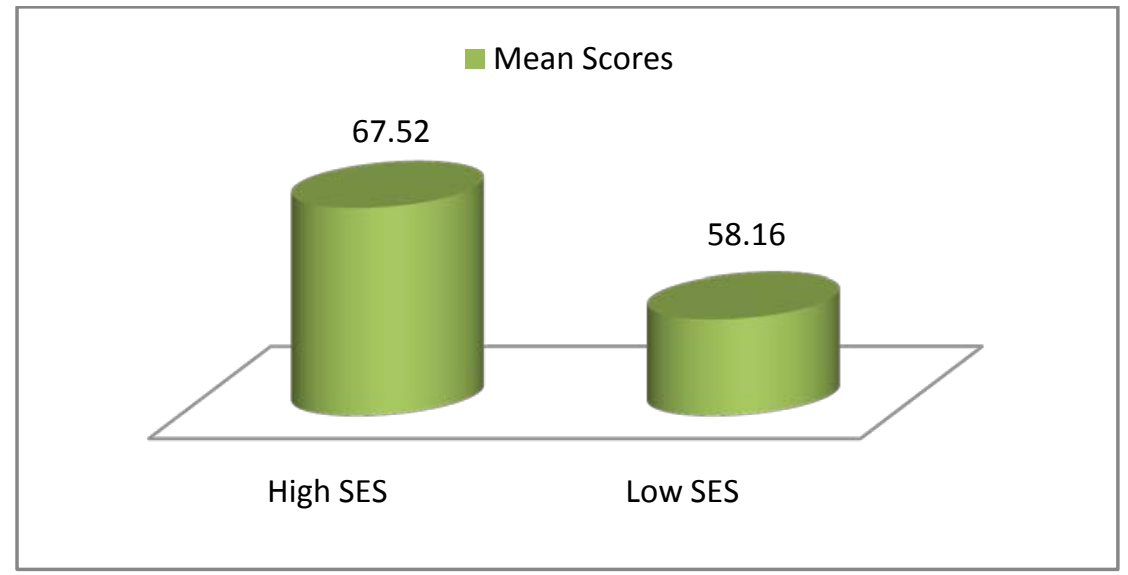

Table-2, Showing Mean, Standard Deviation, Mean Difference, and $t$ value of Middle and Low Socioeconomic Status

\begin{tabular}{|c|c|c|c|c|c|c|}
\hline Group & N & Mean & S.D & M.D & df & t- value \\
\hline Middle SES & 40 & 55.12 & 10.05 & & & \\
Low SES & 40 & 58.16 & 16.99 & 3.03 & 78 & 0.97 \\
\hline
\end{tabular}

Graph -2, Graphical representation of mean scores of Middle and Low Socioeconomic Status

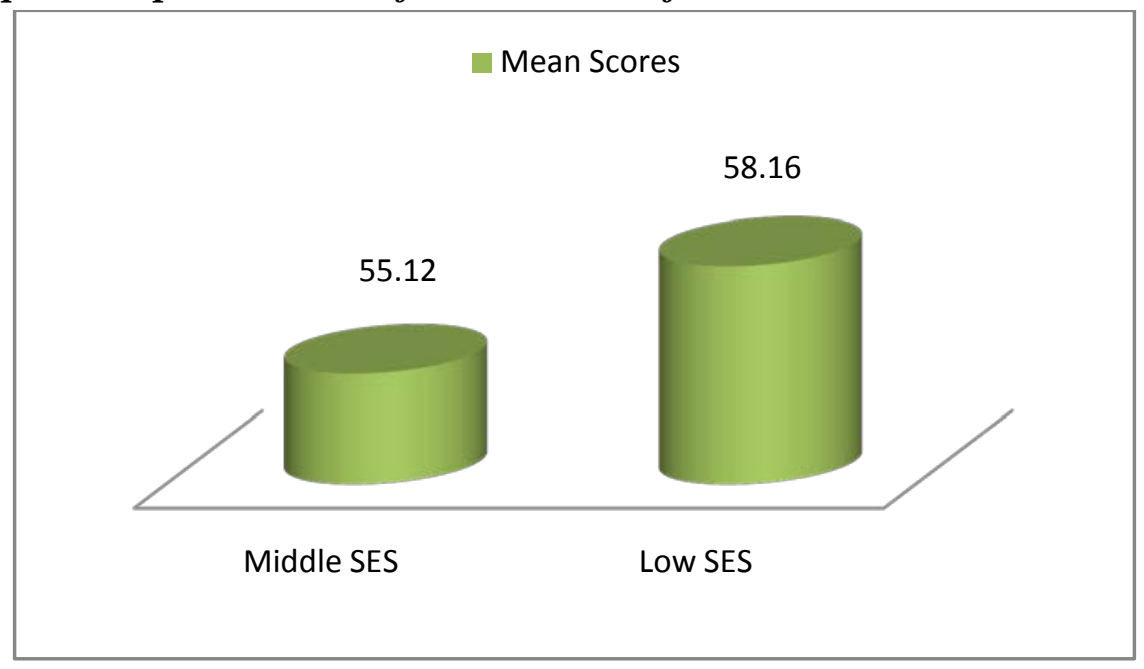

(C) The International Journal of Indian Psychology, ISSN 2348-5396 (e)| ISSN: 2349-3429 (p) | 35 
Effect of Socio Economic Status on Academic Performance of Secondary School Students

Table-3, Showing Mean, Standard Deviation, Mean Difference, and $t$ value of High and Middle Socioeconomic Status

\begin{tabular}{|c|c|c|c|c|c|c|}
\hline Group & N & Mean & S.D & M.D & df & t-value \\
\cline { 1 - 4 } High SES & 40 & 67.52 & 16.86 & & & \\
\cline { 1 - 5 } Middle SES & 40 & 55.12 & 10.05 & 12.39 & 78 & $3.99 * *$ \\
\hline
\end{tabular}

**significant at 0.01 level

Graph-3, Graphical representation of mean scores of High and Middle Socioeconomic Status

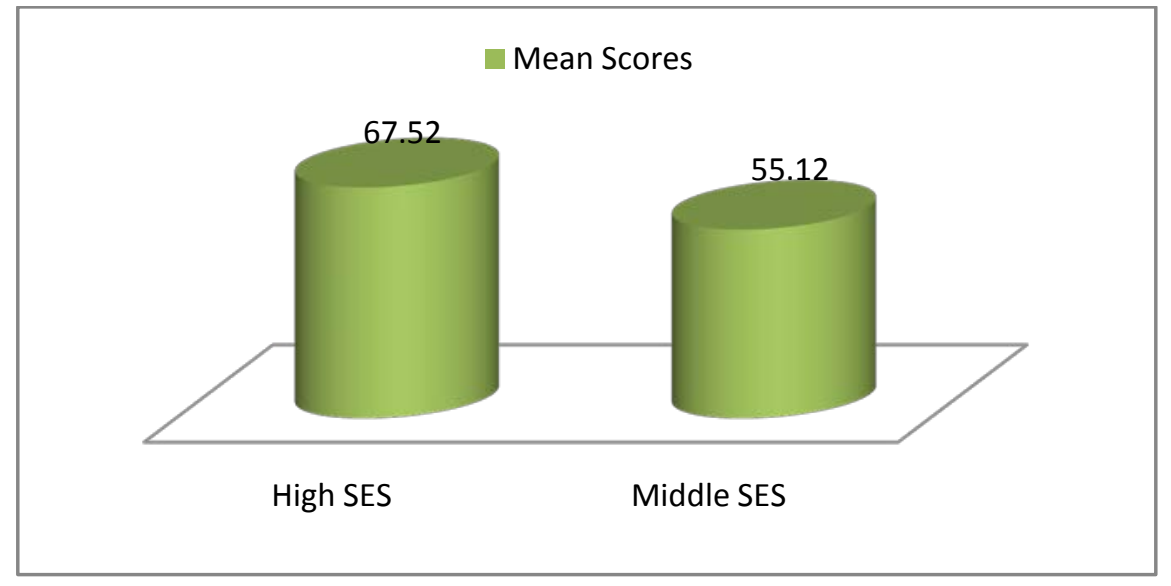

\section{DISCUSSION}

The mean, S.D and M.D of high and low socioeconomic status in respect to academic achievement of students (shown in table-1) was found [( $M=67.52,58.16),(S . D=16.86,16.99)$ and (M.D=9.39)] respectively. The obtained t-value (2.47/78) was found more than tabulation value at 0.05 (1.99) level of significance. Thus our findings suggests that students with high socioeconomic status have high academic achievement than students with low socioeconomic status on the basis of our findings we can say our first hypothesis (There would be significant difference on achievement of students between high and low socioeconomic status) is accepted.

Our $2^{\text {nd }}$ hypothesis (There would be significant difference on academic achievement of students between middle and low socioeconomic status.) is rejected as the obtained t-value (0.97/78) was found insignificant at 0.05 (1.99) level of significance. The obtained mean scores of students from the families with middle socioeconomic status was found (55.12) which is less than mean scores (58.16) of students from the families with low socioeconomic status. Similarly the S.D and M.D of the same group was found [(S.D=16.86, 16.99) and (M.D=9.39)] respectively.

The final hypothesis of the present study (There would be significant difference on academic achievement of students between high and middle socioeconomic status.) is also accepted as the obtained t-value (3.99/78) was found significant at 0.01 (2.63) level of significance. The obtained mean scores of students belongs to high socioeconomic status was found (67.52) which is more than mean scores (55.12) of students belongs to middle socioeconomic family. Similarly

(C) The International Journal of Indian Psychology, ISSN 2348-5396 (e)| ISSN: 2349-3429 (p) | 36 


\section{Effect of Socio Economic Status on Academic Performance of Secondary School Students}

the S.D and M.D of the same group was found [(S.D=16.86, 10.05) and (M.D=12.39)] respectively. Thus the results of the present study reveal that students with high socioeconomic status have high academic achievement than students with middle socioeconomic status.

\section{CONCLUSION}

To sum up, taking into account the findings of the present study, we might conclude that socioeconomic status is the significant factors in academic achievement.

\section{REFERENCES}

Eamon, M., K. (2005). Social demographic, school, neighborhood and parenting influences on academic achievement of Latino young adolescents. Journal of Youth and Adolescence, 34(2), 163-175.

Rothestein, R. (2004). Class and schools using social economic and educational reforms to close the white and black achievement gap. Economic Policy Institute, U.S.A.

Sabzwari G., R. (2004). A Study on the Effects of Parental Socioeconomic Status on the Disciplined Behavior of their Adolescent Children Studying in Secondary Classes, Islamabad: Unpublished Ph.D. Thesis, Allama Iqbal Open University.

Saifi, S., \& Mehmood, T. (2011). Effects of socio-economic status on student's achievement. International Journal of Social Sciences \& Education, 1, 2:119-128.

Suleman, Q., Aslam, H., D, Shakir, M., Akhtar, S., Hussain, I., \& Akhtar, Z. (2012). Effects of Family Structure on the Academic Performance of Students at Elementary Level in District Karak, Khyber Pakhtunkhwa (Pakistan). Journal of Sociological Research, 3, 2.

How to cite this article: M Bhat, J Joshi, I Wani (2016), Effect of Socio Economic Status on Academic Performance of Secondary School Students, International Journal of Indian Psychology, Volume 3, Issue 4, No. 56, ISSN 2348-5396 (e) | ISSN: 2349-3429 (p), DIP: 18.01.004/20160304, ISBN: 978-1-365-23992-2 